\title{
Conditions and perceptions of the urban poor
}

\author{
Dr. Padmaja Chetia \\ Assistant Professor, Department of Economics, Kamrup College, Chamata, Nalbari, India
}

\begin{abstract}
The world is undergoing biggest wave of urban growth in history. In 2008, for the first time in history, more than half of the world's population resides in towns and cities. By 2030 this figure will be almost 5 billion and most of the urban growth will be concentrated in Africa and Asia. While mega cities have already witnessed the growth and captured public attention, this recent urban growth is take place in smaller towns and cities, which have less resource to respond to the magnitude of the growth. Due to rapid urbanization, the urban poverty is becoming a significant area of intervention. In order to gain a deeper, locally specific understanding of urban poverty, it is very essential to ask the local poor people to give their own perceptions of what it is like to be poor. The perceptions of the urban poor have to be identified in order to know their problems. The intention is to gain an understanding and insights into the lives of the urban poor through their eyes. When people define their poverty, their experiences of poverty are varied and complex. This paper therefore makes a humble attempt to study about the conditions, perceptions and coping strategies of the urban poor. The present research work is based mainly on primary data.
\end{abstract}

Keywords: Coping strategies, Multidimensional poverty, Perception, Urban growth, Urbanization, Urban poverty, Urban poor.

\section{Introduction}

Urbanization is an important demographic shift worldwide. Developing countries accounts for a large and rapidly increasing proportion of world's urban dwellers. But men and women migrating to cities in search of better opportunities and more secure livelihood frequently fail to find either and eventually add to the existing number of poor.

Although cities are centres of production, employment and innovation, the rapid urbanization also manifests itself in the form of congestion, inadequate infrastructure, housing shortage, poor access to basic urban services and proliferation of slums with degraded environment.

Perceptions of urban poverty started to change in the late 1980s. There are a number of ways to define poverty in general and urban poverty in particular. The narrower view defines poverty as inadequate income or inadequate consumption. But the broader conception of urban poverty involves eight interrelated sets of deprivation: inadequate income, inadequate shelter, inadequate provision for public infrastructure, inadequate provision of basic services, limited or no safety net, inadequate protection of poorer groups' rights through the operation of the law and poorer groups' voicelessness and powerlessness within political systems and bureaucratic structure [1].

The poor in most urban settings live in overcrowded and unsanitary slums and squatter settlements. They lack good health facilities, housing and services. The poor at the same time lack tenure security and are vulnerable to insecurity, diseases and natural and man-made disasters. Because of their vulnerability and inability to influence decisions in their settings, the poor also suffer from poverty of power. More often than not, the poor lack information to advance their case. Urban poverty is thus a multidimensional phenomenon.

\subsection{Objectives}

In order to gain a deeper, locally specific understanding of poverty, it is very essential to ask the local poor people to give their own perceptions of what it is like to be poor. The perceptions of the poor have to be identified in order to know their problems. The intention is to gain an understanding and insights into the lives of the poor through their eyes. When people define their poverty, their experiences of poverty are varied and complex. Though these studies may not be representative of the whole situation in the city, they give indications on the conditions, perceptions and coping strategies of the urban poor. This study therefore makes a humble attempt to study about the -

- urban poors' conceptualisation of their situation

- causes of poverty as understood by the urban poor

- coping strategies utilised by the urban poor to overcome their difficult situation 


\subsection{Significance}

The study has several areas of significance. Many of the studies of urban poverty in India are done in bigger cities but the characteristics of the urban poor areas in these cities may not be same for those in the medium sized cities such as, Guwahati. The findings and solutions to urban poverty in bigger cities may not be appropriate to the medium or small sized cities. Therefore, the theoretical significance of the study lies in the understanding of multidimensional urban poverty at the micro-level, i.e, at the local level. Practically, the study is expected to help the policy makers in designing effective strategies to reduce urban poverty by understanding the problem in the local context.

\subsection{Study area and Methodology}

This study was carried out in the city of Guwahati, the capital of Assam and the only metropolitan city in the entire North Eastern Region of India. It is also the entry point for the South East Asian Region. According to a survey done by a UK media outlet, Guwahati is among the 100 fastest growing cities of the world, and is the 5th fastest growing among Indian cities. The city's population grew from just two hundred thousand in 1971 to more than five hundred thousand in 1991 and as per official census report of 2011, Guwahati's population was found to be 963,429 . Now it is a million plus city. At present the city is subdivided into 60 municipal wards covering an area of 216 sq.km

The core of the study depended on the primary information collected through fieldwork. The sample for primary investigation has been selected with a two-stage sampling design fitted to the requirements to the study. In the first stage four wards with highest concentration of urban poor households have been selected from the 90 slum and urban poor pockets as identified by Guwahati Municipal Corporation. In the second stage from each of the selected ward about $10 \%$ of the households have been selected at random.

The four wards selected are ward12( sites- Katabari,Gorsuk,Garopara,Fatashil Nagar, Krishna nagar, Shankardev Nagar and Ambikagori nagar), ward 17(sites- Nalmati, Nalapara, Milan nagar and Naibaw), ward 34(sites- Rajabari,Uzanbazar) and ward 41( site- Mailatanki Basti). The research sites of the first two wards are hilly areas and last two wards are plain areas.

\section{Conception of their situation}

The poor conceptualized their own situations. The "Table 1" reveals that respondents with higher income are happier than those in the lower income groups. But majority of the respondents $(52.0 \%)$ explain their life as miserable whereas $32.2 \%$ of the respondents conceptualise their situation as mixed.

Table 1: distribution of respondents by income groups (in rupees) and conception of situation

\begin{tabular}{|c|c|c|c|c|c|}
\hline \multirow{2}{*}{$\begin{array}{l}\text { Income } \\
\text { groups }\end{array}$} & \multicolumn{4}{|c|}{ Conception of situation } & \multirow[t]{2}{*}{ Total } \\
\hline & Happy & Mixed & Miserable & No response & \\
\hline Upto 1499 & -- & $.3 \%$ & $14.8 \%$ & $2.8 \%$ & $7.7 \%$ \\
\hline $1500-2999$ & $.9 \%$ & $2.8 \%$ & $28.0 \%$ & -- & $31.7 \%$ \\
\hline $3000-4999$ & $4.0 \%$ & $24.9 \%$ & $8.9 \%$ & $.3 \%$ & $38.2 \%$ \\
\hline 5000 and above & $5.8 \%$ & $6.2 \%$ & $.3 \%$ & -- & $12.3 \%$ \\
\hline Total & $10.8 \%$ & $34.2 \%$ & $52.0 \%$ & $3.1 \%$ & $100.0 \%$ \\
\hline
\end{tabular}

source: field survey

The conceptualisation of the situation can be shown with the help of a pie- diagram as shown in Fig 1.

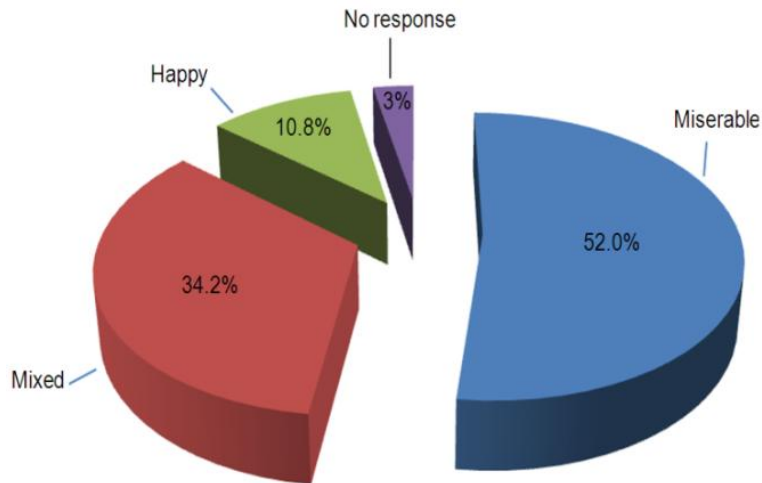

Fig. 1: conceptualisation of situation by the poor source: field survey 


\section{Causes of poverty}

The causes of poverty as identified by the urban poor are various and complex and have many deepseated roots that could be grouped under three heads: physical, human and economic and there by reflected the multidimensional nature of poverty. The human factor stemmed from the micro level as it emanated from the individual characteristics such as lack of education and awareness, health problems, big family size etc. The physical and economic factors arose from the macro level as the causes are linked to the institutional power which failed to facilitate the poor's access to the basic needs and services.

Among all the reasons of poverty cited by the poor as shown in "Table 2", the ten most prominent are price rise (94.8\%), inefficient and ineffective government (90.2\%), lack of information and awareness (84.6\%), low income and no savings (60.6\%), lack of regular employment (58.8\%), illiteracy (57.2\%), lack of infrastructure (52.6\%), no land and house (49.6\%), insecurity of tenure (44.3\%) and big family (43.4\%).

Table 2: causes of poverty according to the perceptions of the poor in the four wards

\begin{tabular}{|c|c|c|c|c|c|c|}
\hline \multirow{2}{*}{\multicolumn{2}{|c|}{ Causes of poverty }} & \multicolumn{4}{|c|}{ Wards } & \multirow[b]{2}{*}{ Total } \\
\hline & & Ward 12 & Ward 34 & Ward 17 & Ward 41 & \\
\hline \multicolumn{7}{|c|}{ Physical } \\
\hline & $\begin{array}{l}\text { Lack of infrastructure(roads, drinking water, drainage, } \\
\text { electricity) }\end{array}$ & $8.9 \%$ & $16.0 \%$ & $14.2 \%$ & $13.5 \%$ & $52.6 \%$ \\
\hline - & No land/house & $11.4 \%$ & $14.8 \%$ & $5.5 \%$ & $17.8 \%$ & $49.5 \%$ \\
\hline \multicolumn{7}{|c|}{ Human } \\
\hline$\bullet$ & Illiteracy & $14.5 \%$ & $16.0 \%$ & $14.2 \%$ & $12.6 \%$ & $57.2 \%$ \\
\hline$\bullet$ & Death/separation from husband & $7.1 \%$ & $5.5 \%$ & $2.2 \%$ & $4.0 \%$ & $18.8 \%$ \\
\hline$\bullet$ & Ill health & $11.7 \%$ & $4.0 \%$ & $3.1 \%$ & $10.5 \%$ & $29.2 \%$ \\
\hline$\bullet$ & Lack of awareness & $24.6 \%$ & $18.2 \%$ & $16.0 \%$ & $25.8 \%$ & $84.6 \%$ \\
\hline$\bullet$ & Big family & $7.1 \%$ & $22.5 \%$ & $4.9 \%$ & $8.9 \%$ & $43.4 \%$ \\
\hline - & Alcoholism/gambling & $.3 \%$ & $1.2 \%$ & $.9 \%$ & $2.5 \%$ & $4.9 \%$ \\
\hline \multicolumn{7}{|c|}{ Economic } \\
\hline$\bullet$ & Insecurity of tenure & $13.2 \%$ & $12.9 \%$ & $10.8 \%$ & $7.4 \%$ & $44.3 \%$ \\
\hline$\bullet$ & Lack of employment & $17.8 \%$ & $13.8 \%$ & $9.5 \%$ & $17.5 \%$ & $58.8 \%$ \\
\hline$\bullet$ & Low income/ no savings & $16.3 \%$ & $17.8 \%$ & $8.0 \%$ & $18.5 \%$ & $60.6 \%$ \\
\hline$\bullet$ & Inefficient government & $25.8 \%$ & $21.8 \%$ & $16.3 \%$ & $26.2 \%$ & $90.2 \%$ \\
\hline$\bullet$ & Price rise & $28.9 \%$ & $23.4 \%$ & $16.3 \%$ & $26.2 \%$ & $94.8 \%$ \\
\hline
\end{tabular}

source: field survey

The urban poor in the four wards have indicated that the high general price is a prominent cause of poverty because they have to purchase everything from the retail shops. The fair price shops do not have all the items as cited by the respondents having BPL cards and a vast majority does not have the cards as some of them are recent migrants and some others could not get even after giving bribes to the authority.

They also identified inefficiency and ineffectiveness of the government in solving their problems. They believe that the government can do a lot for them but if the government is reluctant then not even God can help them. Some of the respondents commented that the people of the government come to their localities only at the time of election. The following problems existing in government poverty alleviation activities are identified by some of the poor: i) government officials don't listen to the poor and don't understand the needs of the poor and ii) lack of coordination and cooperation among different government departments result in low efficiency and low effectiveness in helping the poor.

Another reason is their lack of information and awareness, due to their illiteracy, of what the government is doing for them and could not reap the benefits of the government's schemes.

Irregular income and zero savings due to lack of regular paid employment make difficult to make both ends meet. Some families have to survive with one meal a day. The rainy season is identified as the most troublesome period. During this period the poor suffer from falling income levels because of fall in demand for 
casual labour, reduced customers for small traders and frequent ill-health due to water-borne diseases. The vendors always have a tough time because they are frequently chased by police and municipal authorities.

Lack of infrastructure like roads, water supply, electricity etc, insecurity of tenure and no housing of own have made their life miserable.

Big family size with 5 to 8 members depending on single income earner poses another prominent reason of their poverty.

\section{Coping strategies of the urban poor}

The study reveals that the urban poor face extreme poverty and vulnerability in terms of their economic and social conditions. The ability to avoid or reduce poverty depends not only on having assets but also the capacity to manage them and to transform them into income, food and other basic necessities. The urban poor residents have adopted and adapted various strategies to survive in the city and to cope with impoverishment and the increasing administrative and financial incapacity of urban governments. The coping strategies of the poor are found out to be large and diverse as shown in "Table 3".

The various strategies can be grouped under five heads: 1) income raising strategy 2) expenditure minimizing strategy 3) strategies taken during eviction 4) social and economic infrastructure options and 5) social network.

\subsection{Income raising strategy}

The urban poor are mostly employed in self managed low paid jobs in the informal urban sectors like daily wage labour, rickshaw pulling, street vending and selling etc. A small proportion works in government and private organizations. The rates of income, wage and productivity are very low among the urban poor.

Putting more household members into the workforce is the main survival strategy of the urban poor. Some of the urban poor use their domestic spaces for both production and reproduction through incomegenerating activities. Some also let out a part of their house and some others lend their savings to earn extra income. Tapping of electricity line is also allowed by some households to make extra money

\subsection{Expenditure minimizing strategy}

The urban poor change their dietary habits to minimize their expenditure. Their earnings are spent mostly to fulfill their basic needs of food and shelter. Meager expenditures are made on clothing, medicine, education and other needs. The urban poor mainly buy items like rice, oil and other groceries at a low cost from retail shops located in their neighbourhoods but rarely go to the cheaper wholesale markets. They depend on cheap and less nutritious food. They collect rotten vegetables from the market. They also depend on bad quality

Table 3: coping strategies of the urban poor

\begin{tabular}{|c|c|}
\hline Income raising strategy & $\begin{array}{l}\text { - Increased the number of members, both women and children, in earning income } \\
\text { - Some poor households lend their savings to earn an extra income } \\
\text { - Some households use their homes for production and sale of food and country liquor } \\
\text { - A small percentage of home owners earn extra income from rent } \\
\text { - Tapping of electricity line is also allowed by some households to make extra money }\end{array}$ \\
\hline Expenditure minimizing strategy & $\begin{array}{l}\text { - Changing dietary habits by reducing the number of meals } \\
\text { - Buying cheaper or less nutritious food. Some households use to collect the rotten } \\
\text { vegetables from the market place. } \\
\text { - Buy bad quality fish and fruits at low price } \\
\text { - Some poorest households rarely buy new clothes but get it from employers or sometimes } \\
\text { - Households goods are also purchased from second hand shops } \\
\text { - Cutting back on the purchase of non food and non essential goods }\end{array}$ \\
\hline Eviction & $\begin{array}{ll}\text { - } & \text { Some go to village homes } \\
\text { - } & \text { Few households stay in rented house } \\
\text { - } & \text { Majority of the households stay together under a tirpal } \\
\end{array}$ \\
\hline Social and economic infrastructure & $\begin{array}{l}\text { - Families with many members live in one congested room } \\
\text { - In case of insufficiency of drinking water, households borrow from neighbours and some } \\
\text { purchased water } \\
\text { - Some of the electricity connections are illegal } \\
\text { - When ill, they opt for pharmacist, traditional healer and offering puja to deities } \\
\text { - Any problem regarding access to various services, they solve with the help of neighbours }\end{array}$ \\
\hline Social network & $\begin{array}{l}\text { - Both economic and social assistance received from household relations living within the } \\
\text { city and in rural areas and } \\
\text { - More social assistance is received from the neighbours }\end{array}$ \\
\hline
\end{tabular}

source: field survey 
fish and fruits at low costs and cannot afford expensive items like milk, meat and fresh fish. The urban poor rarely buy new clothes and other household items from the market places and mostly get them from landlords and employers and from second hand markets. Thus they cut back on the purchase of non food and non essential goods.

\subsection{Survival strategy during eviction}

Some of the poor households frequently face eviction. For sometime, some of the urban poor go to their village homes, few households who can afford stay in rented house and majority of the households stay together in makeshift houses of tirpal (makeshift tent).

\subsection{Social and economic infrastructure}

Any problem regarding access to various services, the urban poor solve with the help of neighbours. In many cases more than five members of the households live in one congested room. They sometimes get electricity connections illegally and from informal sources. In case of insufficiency of drinking water, households borrow from neighbours. When ill, they opt for pharmacist, traditional healer and offering pujas (religious rituals) to deities.

\subsection{Social network}

The urban poor migrated mostly from different rural districts due to various reasons. But after migration to the city the poor migrants fail to achieve their expectations and sometimes they consider their previous life better than the present one. Despite living in the city they never lose the rural-urban ties. In times of difficulties, the urban poor receive both economic and social assistance from household relations living within the city and in rural areas. But more assistance is got from the neighbours. Thus social networking plays an important role for the urban poor in coping with urban life.

The findings of the study can be summed up as follows:

\section{Findings}

- The urban poor have conceptualized their situations as happy (10.8\%), miserable $(52.0 \%)$, mixed (34.2\%) and no response $(3.1 \%)$.

- The causes of poverty according to the perceptions of the poor are physical, human/individual and economic which reflected the multidimensional nature of poverty.

- The coping strategies of the poor in adverse situations are found to be many and diverse. They are income raising strategies, expenditure minimising strategies, survival strategies during eviction, social and economic infrastructure options and social network. But the urban poor depended mostly on readjusting their expenditure patterns.

\section{Conclusion}

In conclusion it can be summed up that from the discussion and interview with the urban poor, it was found that bottom-up and self defined approaches should be introduced to enhance the local understanding of the different dimensions of urban poverty, its complexity and local specificity and to target poverty alleviation more effectively. The urban poor must participate in the whole process of project/programme formulating, planning, and implementation and in policy making. Thus, a training workshop on the introduction and application of participatory approaches in urban poverty alleviation intervention for policy makers, officials and field workers is needed.

\section{Book:}

\section{References}

[1]. Mitlin, Diana, and David Satterthwaite, (Ed), responding to squatter citizens: the role of local governments and civil society in reducing urban poverty (London: Earthscan,2003) 